Блажівська Н. Є., кандидат юридичних наук, докторант

Інституту законодавства Верховної Ради України

\title{
ЗАГАЛЬНА ХАРАКТЕРИСТИКА ЗАСТОСУВАННЯ ПРАКТИКИ ЄВРОПЕЙСЬКОГО СУДУ З ПРАВ ЛЮДИНИ ПІД ЧАС ЗАХИСТУ ЗОБОВ’ЯЗАЛЬНОГО ПРАВА ВИМОГИ
}

Анотація. Стаття присвячена розкриттю загальної характеристики застосування практики Європейського суду 3 прав людини під час захисту зобов'язальних прав вимоги. На підставі аналізу практики Свропейського суду 3 прав людини виділено дві умови захисту зобов'язального права вимоги в практиці Європейського суду з прав людини. По-перше, зобов'язальне право вимоги повинно мати майновий характер. По-друге, зобов'язальне право вимоги повинно бути зумовлене положеннями національного законодавства та практики його застосування або безпосередньо підтверджене судовим рішенням.

Ключові слова: практика Європейського суду з прав людини, легітимне (законне) очікування, зобов'язальне право вимоги.

Постановка проблеми. Практика Європейського суду 3 прав людини (далі - ЄСПЛ) визнана як джерело права в Україні, має полігалузевий характер, тобто однаковою мірою застосовна як до публічно-правових, так і приватноправових відносин. Це повною мірою стосується цивільного права на рівні як цілих підгалузей, так і окремих інститутів. Автономне та динамічне тлумачення положень Конвенції про захист прав людини й основоположних свобод (далі - ЄКПЛ) та протоколів до неї дало можливість ЄСПЛ поширити їхню дію на права, які безпосередньо не закріплені в самій Конвенції. Одним із таких є суб'єктивне цивільне право вимоги, яке виникає із зобов'язань, що охоплюється змістом ст. 1 Першого Протоколу до Конвенції (далі - Перший Протокол).

Аналіз останніх досліджень і публікацій. Практика ЄСПЛ досить широко використовується як емпірична база в сучасних цивілістичних дослідженнях, зокрема в тих із них, які стосуються зобов' язального права. Однак праці, які 6 комплексно розкривали застосування практики ЄСПЛ до зобов'язальних відносин, є поодинокими. Серед них треба виділити такі статті: О.П. Подцерковного «Універсалізація поняття зобов'язання як фактор розвитку галузей права», що пояснює «суперечливу» практику ЄСПЛ щодо широкого тлумачення поняття «цивільні права», яке охоплює не тільки права та обов'язки «приватного характеру» в класичному розумінні, але й будь-який спір у сфері посягання на майнові права [1, с. 193-194]; О.А. Беляневич «Поняття легітимних очікувань та проблеми його застосування судами України», яка аналізує застосування вітчизняними судами конструкції «легітимних (законних) очікувань», що не відома вітчизняній системі права та не має будь-яких аналогів як об'єкт правового захисту [13, с. 41-45].

Мета статті полягає в 3'ясуванні загальних умов захисту зобов’язального права вимоги відповідно до практики ЄСПЛ.
Виклад основного матеріалу дослідження. Загальновизнаним є те, що зобов'язальне право вимоги охоплюється захистом ст. 1 Першого протоколу [2, с. 686]. Прикладом може служити справа "Regent Company v. Ukraine" [3], в якій предметом спору було виконання арбітражного рішення міжнародного комерційного арбітражу та передача права вимоги іншій комерційній особі. Проаналізуємо прецедентну практику ЄСПЛ щодо захисту зобов'язального права вимоги.

У справі «Прессос Компанія Нав'єра А.О. та інші проти Бельгіï» ("Pressos Compania Naviera S.A. and Others v. Belgium") [4] двадцять шість заявників (серед яких судновласники, асоціації взаємного страхування судновласників, конкурсний управитель судноплавної компанії) подали позов проти Бельгії та оператора приватних лоцманських служб у зв'язку з аваріями, що мали місце на суднах. Виникнення спірної ситуації пов'язується заявниками 3 рішенням Касаційного суду Бельгії від 15 грудня 1983 року, яким судновласнику або фрахтувальнику було надано право у разі завдання шкоди внаслідок зіткнення суден або інших аварійних ситуацій подати позов про відшкодування шкоди організатору лоцманських послуг, які раніше, відповідно до закону, не несли майнової відповідальності за таку шкоду. А втім, наступним Законом Бельгії у 1988 році було не лише відновлено попередні положення про відсутність відповідальності організаторів лоцманських послуг, але й надано цьому Закону зворотної дії в часі на всі подібні випадки, що траплялись протягом попередніх 30 років.

Заявники скаржились на норми Закону 1988 року із двох підстав: 1) звільнивши організатора лоцманської служби від відповідальності за помилки його персоналу та обмеживши його відповідальність лише відповідальністю самого персоналу за ці помилки, Закон, на думку заявників, покладає на них надмірний тягар, порушуючи справедливу рівновагу між вимогами суспільного інтересу та вимогами захисту їхнього права безперешкодно користуватись своїм майном. Отже, порушується другий абзац чи принаймні перша фраза ст. 1 Першого Протоколу до Конвенції; 2) зворотна дія закону в часі позбавляє заявників права на відшкодування завданої шкоди, що суперечить другій фразі першого абзацу цієї ж статті Першого Протоколу (§ 28 рішення).

У світлі цього Суд вирішував кілька взаємопов'язаних питань: наявність «майна» в розумінні ст. 1 Першого Протоколу до Конвенції, наявність втручання та його обгрунтованість крізь призму відповідності загальним інтересам і співрозмірності. 3 приводу першого $з$ них Суд зазначив, що для того, щоб визначити, чи йдеться в цьому випадку про наявність «майна», потрібно взяти до уваги внутрішнє законодавство, яке діяло 
на момент ймовірного порушення, оскільки в Суду немає підстав припускати, що воно суперечить ст. 1 Першого Протоколу до Конвенції. Суд вказав на те, що йдеться про аквелійський режим, який породжує вимоги про відшкодування непередбачуваної шкоди, що можуть мати майновий характер та охоплюються першою фразою ст. 1. Крім того, враховуючи вказане вище рішення Касаційного суду Бельгії, заявники могли «правомірно припускати», що їхня вимога стосовно відшкодування збитків у зв'язку з аваріями розглядатиметься як така на основі загальних принципів відповідальності за завдання шкоди ( $\S 31-32$ рішення).

Уперше концепцію «законно обгрунтованого сподівання» ЄСПЛ дослідив у справі «Пайн Веллі Девелопментс Лтд. та інші проти Ірландіï» ("Pine Valley Developments Ltd and Others v. Ireland") [5], де встановив, що таке сподівання виникає на підставі чинного національного закону, породжуючи виправдане сподівання в його подальшому дотриманні (у цій конкретній справі - за умови, коли було видано дозвіл на планування, на підставі якого компанії заявника придбали землю з метою їх розроблення та який не міг бути відкликаний відповідним органом влади, було визнано «складовою частиною власності компаній заявника»).

Далі, в аналізованій справі «Прессос Компанія Нав’єра А.О. та інші проти Бельгії» Суд розглянув питання наявності, обгрунтованості та співрозмірності втручання держави в право заявників мирно володіти й розпоряджатись своїм майном. ЄСПЛ вказав на те, що Закон 1988 року становив собою втручання у права вимоги заявників на відшкодування збитків, які відповідно до чинного внутрішнього права могли бути реалізовані до прийняття цього Закону та, відповідно, втручання у право будь-якої особи, зокрема заявників, на безперешкодне користування своїм майном ( 34 рішення). Врахувавши право держави широко тлумачити поняття «інтереси суспільства», Суд, утім, вказав на недотримання принципу необхідної рівноваги між забезпеченням загальних інтересів і тягарем, що покладається на заявників. Наприклад, за невиплати певної суми, що приблизно відповідає вартості майна, позбавлення власності в принципі є серйозним порушенням, а невиплата компенсації може бути виправдана на основі ст. 1 лише за виняткових обставин. Натомість Закон 1988 року фактично ліквідував, зі зворотною дією в часі на 30 років та без компенсації, вимоги (зокрема, ті, що вже $є$ предметом судових процесів) 3 відшкодування збитків на дуже великі суми, з якими жертви нещасних випадків могли звернутись до Бельгії або до винних приватних компаній (§§ 38-39 рішення).

Також Суд підкреслив, що фінансові міркування, на які посилався Уряд, а також його прагнення наблизити бельгійське законодавство до права сусідніх держав, могли виправдати прийняття майбутнього законодавства, але не надання закону зворотної дії в часі, ціль та дія якої спрямовані на позбавлення заявників права на відшкодування збитків, що є серйозним втручанням у права заявників, порушуючи справедливий баланс інтересів і ст. 1 Першого Протоколу до Конвенції в тій частині, в якій Закон 1988 року стосується фактів, що мали місце до 17 вересня 1988 року, тобто до моменту його опублікування та набрання чинності ( $\$$ 43-44 рішення).

У справі «Стретч проти Сполученого Королівства» (“Stretch v. the United Kingdom") [6] заявник скаржився на те, що був позбавлений місцевою владою та національними судами права поновлення договору лізингу, що призвело до порушення його права мирно володіти своїм майном всупереч ст. 1 Першого Протоколу до Конвенції. При цьому заявник пов'язував вказане порушення не з безпосереднім позбавленням можливості поновити договір лізингу, а 3 договірними та майновими правами за ним: законним правом на винагороду за укладення договору (який він втратив) та зменшення вартості його інвестицій у власність (яку він частково втратив), що, загалом, кореспондували його здатності користуватись власними бізнес-активами взагалі як «майном» у розумінні ст. 1 Першого Протоколу до Конвенції. Також заявник вказував на те, що позбавлення його майна є неспівмірним стосовно будь-якої реальної або презюмованої вигоди в загальних інтересах, підкреслюючи факт відсутності виплати будь-якої компенсації ( $\$ 27-29$ рішення).

У цій справі Суд розглянув аналогічні справі «Прессос Компанія Нав'єра А.О. та інші проти Бельгії» питання стосовно наявності «майна» у розумінні ст. 1 Першого Протоколу до Конвенції, втручання у його володіння та його достатності обгрунтованості такого втручання, встановивши таке. Суд використовував запроваджену в аналізованих нами вище рішеннях категорію «законного сподівання» («легітимного очікування»), вказавши на те, що, попри доводи представників держави стосовно дій відповідних органів місцевої влади ultra vires під час укладення договору лізингу, заявник мав принаймні законні сподівання щодо використання ним надалі можливості поновити договір лізингу (на це вказували як дії заявника з розбудови земельної ділянки, сплати ним лізингових платежів тощо, так і відсутність в обох сторін знання з приводу будь-якої законної перешкоди для поновлення дії договору), що для потреб ст. 1 Першого Протоколу до Конвенції може вважатись пов'язаним із майновими правами, наданими йому органами місцевої влади згідно з договором лізингу ( $\S 34-35$ рішення).

3 приводу наявності втручання у мирне володіння майном або позбавлення такого права, а також обгрунтованості цих дій (співрозмірності між загальними інтересами та правами власності заявника), Суд поставив під сумнів дотримання державою вказаного принципу пропорційності (співрозмірності) під час застосування нею доктрини ultra vires, вказавши на відсутність при цьому в діях органів місцевої влади будь-чого, що саме по собі викликало б заперечення або було б недопустимим чи не відповідало б суспільним інтересам, включно з умовою про можливість поновлення договору лізингу. Також Суд підкреслив, що заявник мав не тільки сподівання на повернення інвестованих за договором лізингу коштів у майбутньому, але й законне очікування на продовження строку цього договору як важливої його умови для особи, що бере на себе зобов'язання з будівництва споруд і яка в іншому разі мала б обмежений часовий період для того, щоб окупити свої витрати. Отже, ЄСПЛ дійшов висновку, що відбулось порушення ст. 1 Першого Протоколу до Конвенції у зв'язку з неспіврозмірним втручанням у право заявника на мирне володіння своїм майном (§§ 36-41 рішення).

У справі «Грецькі нафтопереробні заводи «Стрен» та Стратіс Андреадіс проти Греції» (“Stran Greek Refineries and Stratis Andreadis v. Greece") [7] заявники 22 липня 1972 року уклали з грецькою державою (управління якою тоді здійснювала військова хунта) договір про побудову нафтопереробного заводу у Мегарському регіоні, що, окрім іншого, передбачав зобов'язання держави викупити відповідну земельну ділянку під 
будівництво заводу. Попри це та незважаючи на заперечення заявників, у листопаді 1973 року Міністерство промисловості та сільського господарства Греції прийняло рішення повернути власнику експропрійовану земельну ділянку та тимчасово зупинити будівельні роботи шляхом вжиття відповідних заходів місцевою поліцією. Під час відновлення ж у Греції демократичного режиму Уряд оголосив про шкідливість цього договору для національної економіки, відмовившись виплачувати компенсації заявникам.

У своїй скарзі до ЄСПЛ заявники стверджували про порушення державою ст. 1 Першого Протоколу до Конвенції, посилаючись на те, що прийняття і застосування державою відповідного закону призвело до позбавлення заявників належних їм майнових прав, зокрема права на отримання грошового боргу, визнаного згідно з рішенням Афінського суду першої інстанції та, особливо, арбітражним рішенням від 27 лютого 1984 року (§ 57 рішення). Для того, щоб визначити, чи в заявників виникло право на «майно» в розумінні ст. 1 Першого Протоколу до Конвенції, Суд повинен був з'ясувати, чи є підстави вважати відповідні рішення суду першої інстанції та рішення арбітражного суду виконуваними. Стосовно першого з них Суд вказав на його неостаточність і залежність від будь-якого перегляду судами вищих інстанцій, але щодо рішення арбітражного суду ЄСПЛ зайняв іншу позицію. Суд наголосив на тому, що має право розглянути та взяти до уваги правове становище сторін, сформоване арбітражним рішенням. Стосовно ж останнього, то Суд вказав на його остаточність та обов' язковість для сторін (зокрема, спираючись на позиції чинного тоді грецького законодавства), відсутність потреби та можливості як його перегляду (а також анулювання національними судами, що встановили відсутність підстав для цього), так і вжиття будь-яких заходів для примусового виконання. Отже, на думку Суду, право заявників на виплату грецькою державою заборгованості конституювало «майно» в розумінні ст. 1 Першого Протоколу до Конвенції (\$§ 59-62 рішення).

У частині встановлення факту втручання держави у здійснення майнових прав заявників та обгрунтованості такого втручання Суд погодився із заявниками стосовно застосування державою положень відповідного закону для фактичного позбавлення їх майна у зв'язку зі скасуванням права на отримання боргу, що виник на підставі остаточного та обов'язкового арбітражного рішення, констатувавши порушення права на мирне володіння своїм майном, гарантованого ст. 1 Першого Протоколу до Конвенції (§§ 63-67 рішення). Далі Суд зауважив, що порушення не є експропріацією чи засобом контролю використання власності, а тому повинно розглядатись крізь призму першого речення першого абзацу ст. 1: Суд повинен встановити, чи було дотримано справедливого балансу між загальними інтересами суспільства та вимогами захисту основоположних прав особи. Визнаючи необхідність розірвання шкідливого для національної економіки договору для демократичної грецької держави та превалювання відповідних інтересів держави над договірними зобов'язаннями за таким договором, Суд, утім, вказав на два важливі аспекти: 1) визнання будь-яких правовідносин із диктаторським режимом недійсними у разі його повалення не можна визнати справедливим, тоді як будівництво нафтопереробного заводу в цьому конкретному випадку треба вважати вигідним для економічної інфраструктури держави; 2) одностороннє розірвання договору не впливає на дію окремих ключових застере- жень, включених у договір, зокрема й арбітражного застереження, принцип автономності якого визнається грецькою правовою системою. Зважаючи на це, на думку Суду, вирішивши втрутитись у судовий розгляд справи у суді касаційної інстанції шляхом прийняття закону про розірвання відповідного договору для визнання арбітражного застереження недійсним та анулювання арбітражного рішення, грецька держава на шкоду інтересам заявників порушила справедливий баланс між необхідністю захисту права власності та потребами загального інтересу. Як результат, Суд визнав порушення ст. 1 Першого Протоколу до Конвенції (§§ 68-75 рішення).

У справі «Федоренко проти України» (“Fedorenko v. Ukraine") [8] заявник скаржився, що був позбавлений прибутку за договором купівлі-продажу нерухомого майна Кіровоградському (сьогодні - Кропивницький) обласному управлінню юстиції (далі - Управління), який передбачає захист від інфляції, посилаючись на ціну свого будинку в перерахунку на долари. Заявник вважає, що відмова Управління повністю виконати договір і відмова внутрішніх судів ввести в дію оскаржуваний пункт позбавили його права на мирне володіння своїм майном, а також позбавила його цього майна, порушуючи ст. 1 Першого Протоколу. Він вважає, що оскаржуване положення договору було правомірним і становило власність у значенні цієї статті. Затримка у виконанні договору, яку не заперечує Уряд-відповідач, завдала йому значних фінансових збитків.

Суд вказав на те, що з червня по серпень 1999 року заявник отримував платежі від держави відповідно до договору. Управління, будучи добре обізнаним щодо умов договору із самого початку, підняло питання про його недійсність на дуже пізній стадії (29 листопада 2000 року), тому Суд вважає, що, зважаючи на специфічні обставини справи, заявник має вважатися таким, який має законні сподівання щодо прибутку відповідно до положення угоди про доларовий еквівалент, що може вважатися правом власності відповідно до положень ст. 1 Першого Протоколу, наданого йому за договором із Управлінням (§§ 23-24 рішення). При цьому Суд констатує, що оскільки сам представник Управління, пан Р., будучи суддею, вважав, що він мав повноваження підписувати договір, то очевидно, що й заявник дотримувався такої ж думки. Тому заявник очікував отримати певний прибуток від цієї угоди. Він намагався прив'язати свої майбутні прибутки до твердої валюти, щоб знизити ризики, можливі у разі здійснення комерційних угод під час економічного безладу, що мав місце в Україні в кінці дев'яностих років. Тому ця умова була важливою частиною договору для заявника, який в іншому разі міг би мати серйозні застереження щодо продажу (§ 31 рішення).

Дослідивши обставини, пов'язані з невиплатою заявнику належних коштів за договором, невідповідністю розрахованої та виплаченої йому компенсації належній сумі, намаганням Управління взагалі анулювати договір у національних судах, ЄСПЛ дійшов висновку, що в цій справі наявне непропорційне втручання до мирного володіння своїм майном, і тому Суд вважає, що відбулось порушення ст. 1 Першого Протоколу до Конвенції (§§ 28-34 рішення).

Ще одне питання, на яке варто звернути увагу, стосується того, що практика ЄСПЛ допускає компенсацію моральної шкоди в договірних зобов'язаннях. Прикладом може служити ця ж справа "Fedorenko v. Ukraine" [8], в якій ЄСПЛ дійшов висновку, що заявник, очевидно, зазнав деяких моральних страждань 
через цей випадок. Тому суд вважає необхідним присудити 3 цього питання виплату компенсації у розмірі 1000 євро» [8].

Також треба розглянути прецеденти, пов'язані 3 присудженням, але не виплатою державою пенсії та інших соціальних виплат заявникам. Наприклад, у справі «Праведная проти Pociï» ("Pravednaya v. Russia") [9] заявниця скаржилась на те, що внаслідок перегляду національними судами ухваленого стосовно неї остаточного рішення за нововиявленими обставинами було зменшено суму отримуваної нею пенсії. Суд, перш за все, зазначив, що право на пенсію за віком або соціальні забезпечення певною сумою як такі не входять до числа прав і свобод, гарантованих Конвенцією. Втім, «вимога», навіть якщо вона стосується пенсії, може виступати «власністю» відповідно до ст. 1 Першого Протоколу до Конвенції, якщо достатньою мірою встановлено, що вимога може бути виконана у примусовому порядку, що в цій справі було підтверджено низкою судових рішень національних судів. При цьому Суд вважає, що внаслідок рішення, яким було задоволено заяву про перегляд справи, заявницю було позбавлено права отримувати пенсію в бажаному розмірі, а звідси й - позбавлення заявниці іiї майна, яке згадується в другому реченні першого абзацу ст. 1 Першого Протоколу (\$§ 37-39 рішення).

Суд підкреслив, що позбавлення майна, відповідно до передбаченого у другому реченні правила, може вважатися обгрунтованим, якщо було доведено, зокрема, що його здійснено «в інтересах суспільства» і «на умовах, передбачених законом». «Інтереси суспільства», звичайно, може ілюструвати ефективна і гармонійна система виплат державної пенсії, для реалізації якої держава може коригувати своє законодавство. Проте можлива зацікавленість держави в забезпеченні однакового застосування Закону про пенсії не повинна була стати причиною для перерахунку (зі зворотною дією в часі) того, що вже було раніше присуджено. Суд вважає, що, позбавляючи заявницю права на отримання пенсії в сумі, визначеній остаточним судовим рішенням, держава порушила справедливий баланс інтересів сторін, відповідно, наявне порушення ст. 1 Першого

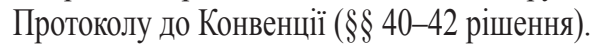

У справі «Суханов та Ільченко проти України» ("Sukhanov and Ilchenko v. Ukraine") [10] заявники скаржилися на невиплату їм державними органами відповідної надбавки до пенсії в розмірі, передбаченому ст. 6 Закону України «Про соціальний захист дітей війни», у періоди з 1 січня 2006 року по 9 липня 2007 року та 31 січня по 22 травня 2008 року. Суд звернув увагу на те, що, маючи право на вищевказану надбавку, заявники мали майнове право відповідно до ст. 1 Першого Протоколу, зазначивши, що зменшення розміру або припинення виплати належним чином встановленої соціальної допомоги може становити втручання у право власності ( $\S 51-52$ рішення). Також Суд знову наголосив на тому, що першим і найголовнішим правилом ст. 1 Першого Протоколу є те, що будь-яке втручання державних органів у право на мирне володіння майном має бути законним і повинно мати легітимну мету «в інтересах суспільства». Будь-яке втручання також повинно бути пропорційним стосовно переслідуваної мети. Інакше кажучи, має бути забезпечено «справедливий баланс» між загальними інтересами суспільства та обов'язком захисту основоположних прав конкретної особи. Необхідного балансу не буде досягнуто, якщо на відповідну особу або осіб буде покладено особистий і надмірний тягар ( 53 рішення).
Суд зазначає, що в період із квітня по грудень 2006 року Кабінет Міністрів України мав визначити розмір надбавки до пенсії, яка підлягала виплаті заявникам. Жодного рішення 3 цього питання не було прийнято. У цьому разі відмова держави здійснити певні дії становила втручання в права заявників, передбачені ст. 1 Першого Протоколу. Уряд не надав жодних пояснень цієї бездіяльності, яка тримала заявників у невизначеності. Тож Суд не бачить жодних причин, чому органи влади не вжили заходів для визначення розміру надбавки до пенсії заявників і вважає це втручання невиправданим. Отже, було порушення права заявників, передбаченого ст. 1 Першого Протоколу, за період з 2 квітня по 31 грудня 2006 року (§§ 54-56 рішення).

У західній науковій думці на основі аналізу вказаних вище висновків у справі «Прессос Компанія Нав’єра А.О. та інші проти Бельгії» та інших аналізованих нами справах й подібних до них справах констатується широкий підхід ЄСПЛ до тлумачення змісту поняття «майна» в розумінні ст. 1 Першого Протоколу до Конвенції. Наприклад, ця категорія охоплює не лише права власності на нерухоме майно, але й права, пов'язані з акціями, права на отримання пенсії та орендної плати, вимоги стосовно повернення майна, відшкодування шкоди згідно з положеннями деліктного права, а також вимоги, пов'язані $з$ наявністю в заявника законно (або на основі судової практики) обгрунтованих сподівань (легітимних очікувань), що таке право власності буде реалізованим [11, с. 65].

Як зазначає О.А. Беляневич, у традиціях українського законодавства та правової традиції, коли йдеться про право вимоги та борг, розуміється наявність зобов'язальних відносин між сторонами та їхній зміст. I для вирішення українськими судами спорів, пов'язаних із неналежним виконанням договорів, немає потреби застосовувати концепцію «законних очікувань» для вирішення питання про задоволення позову кредитора. Уявляється, що і розгляд вимоги про продовження терміну дії договору оренди за українським законодавством так само не потребувало б застосування доктрини легітимних (законних) очікувань [12, с. 43]. Продовжуючи цю думку, О.А. Беляневич робить висновок, що під час застосування автономного поняття «законні очікування» необхідно враховувати таке: 1) в практиці ЄСПЛ речові та зобов'язальні права розглядаються крізь призму автономного поняття «майно»; 2) національне законодавство України дає змогу вирішувати спори, що виникають у зобов'язальних відносинах і стосуються захисту права кредитора, за допомогою наявних правових конструкцій, тому застосування концепції «законних очікувань» невиправдано обтяжуватиме й ускладнюватиме практику; 3) в аспекті забезпечення правового порядку в країні принцип, закріплений в ч. 2 ст. 19 Конституції України, $€$ пріоритетним, i йому не може протиставлятися автономне поняття «законні очікування»; 4) в умовах нестабільного правового порядку переносити на вітчизняний грунт автономні поняття ЄСПЛ треба дуже обережно, оскільки за діями сторони може ховатися недобросовісність [13, с. 152]. Загалом підтримуючи такий підхід зауважимо, що під час тлумачення автономних понять, використаних у практиці ЄСПЛ, повинно бути забезпечено застосування останньої як джерела права. А отже, це не повинно призводити до звуження змісту прав, які визнаються та захищаються в практиці ЄСПЛ. 
Висновки. Отже, практика ЄСПЛ свідчить, що ст. 1 Першого Протоколу охоплює захист права вимоги, яке може бути елементом змісту як договірних, так і позадоговірних зобов'язань, як регулятивних, так і охоронних зобов'язань, зокрема, 3 невиконання державою взятих на себе зобов'язань із соціального забезпечення. Можна виділити принаймні дві умови захисту зобов'язального права вимоги у практиці ЄСПЛ: 1) зобов'язальне право вимоги має майновий характер; 2) зобов'язальне право вимоги зумовлене положеннями національного законодавства та практики його застосування або безпосередньо підтверджене судовим рішенням. Порушення зобов'язального права вимоги може тягнути за собою компенсацію завданої шкоди - як майнової, так і немайнової (моральної).

\section{Jimepamypa:}

1. Подцерковний О.П. Універсалізація поняття зобов'язання як фактор розвитку галузей права. Наукові праці Одеської національної юридичної академії. 2009. Т. 8. С. 192-201.

2. Карсс-Фріск М. Право на власність: питання імплементації статті 1 Першого протоколу до Європейської конвенції з прав людини. У кн.: Європейська конвенція з прав людини: основні положення, практика застосування, український контекст. / За ред. О.Л. Жуковської. К.: ЗАТ «ВІПОЛ», 2004. С. 685-722.

3. Regent Company v. Ukraine: Court Judgment. 03.04.2008. App. 773/03. URL: http://hudoc.echr.coe.int/eng?i=001-85681.

4. Pressos Compania Naviera S.A. and Others v. Belgium, judgment of 20.11.1995. URL: http://hudoc.echr.coe.int/eng?i=001-58056.

5. Pine Valley Developments Ltd and Others v. Ireland, judgment of 29.11.1991. URL: http://hudoc.echr.coe.int/eng?i=001-57711.

6. Stretch v. the United Kingdom, judgment of 03.12.2003. URL: http://hudoc.echr.coe.int/eng?i=001-61173.

7. Stran Greek Refineries and Stratis Andreadis v. Greece, judgment of 09.12.1994. URL: http://hudoc.echr.coe.int/eng?i=001-57913.

8. Fedorenko v. Ukraine, final judgment of 01.09.2006. URL: http://hudoc.echr.coe.int/eng?i=001-75599.

9. Pravednaya v. Russia, final judgment of 30.03.2005. URL: http://hudoc.echr.coe.int/eng?i=001-67506.

10. Sukhanov and Ilchenko v. Ukraine, final judgment of 26.06.2014. URL: http://hudoc.echr.coe.int/eng?i=001-145014.

11. Mardikian L. The right to property as regional custom in Europe. Transnational Legal Theory. № 9:1. P. 56-84.
12. Беляневич О.А. Поняття легітимних очікувань та проблеми його застосування судами України. Приватне право і підприємництво. 2016. Вип. 16. С. 41-45.

13. Беляневич О.А. Стабільність, безпека цивільного обороту і розумні очікування. Право власності: європейський досвід та українські реалії: збірник доповідей і матеріалів Міжнародної конференції (м. Київ, 22-23 жовтня 2015 р.). К.: «ВАITE», 2015. С. 143-155.

Блаживская Н. Е. Общая характеристика применения практики Европейского суда по правам человека при защите обязательственного права требования

Аннотация. Статья посвящена раскрытию общей характеристики применения практики Европейского суда по правам человека при защите обязательственных прав требования. На основании анализа практики Европейского суда по правам человека выделено два условия защиты обязательственного права требования в практике Европейского суда по правам человека. Во-первых, обязательственное право требования должно носить имущественный характер. Во-вторых, обязательственное право требования должно быть обусловлено положениями национального законодательства и практики его применения или непосредственно подтверждено судебным решением.

Ключевые слова: практика Европейского суда по правам человека, легитимное (законное) ожидание, обязательственное право требования.

Blazhivska N. General characteristics of application of European Court of Human Rights case law for protection of incorporeal right

Summary. The article deals with the disclosure of the general characteristics of the application of the European Court of Human Rights case law for protection of incorporeal rights. Based on the analysis of the European Court of Human Rights case law two conditions for the protection of the incorporeal rights under the European Court of Human Rights case law are highlighted. First, the incorporeal rights must be proprietary. Secondly, the incorporeal rights must be stipulated by the provisions of national legislation and the practice of its application or directly confirmed by a court decision.

Key words: European Court of Human Rights case law, legitimate (reasonable) expectations, incorporeal rights. 